\title{
Magnesium parameters and their association with lipid metabolism markers in obese women
}

\section{Parámetros de magnesio y su asociación con marcadores de metabolismo de los lípidos en mujeres obesas}

\author{
Loanne Rocha dos Santos ${ }^{1}$. https://orcid.org/0000-0002-5418-6715 \\ Stéfany Rodrigues de Sousa Melo ${ }^{1}$. https://orcid.org/0000-0001-5308-3522 \\ Juliana Soares Severo'. https://orcid.org/0000-0002-1771-7871 \\ Jennifer Beatriz Silva Morais ${ }^{1}$. https://orcid.org/0000-0002-9055-7851 \\ Jessica Batista Beserra'. https://orcid.org/0000-0001-9420-0166 \\ Larissa Cristina Fontenelle1. https://orcid.org/0000-0003-0156-6105 \\ Ana Raquel Soares de Oliveira'. https://orcid.org/0000-0001-5383-0137 \\ Kyria Jayanne Clímaco Cruz ${ }^{1}$. https://orcid.org/0000-0002-4489-702X \\ Mickael de Paiva Sousa ${ }^{1}$. https://orcid.org/0000-0002-8446-1351 \\ Francisco Erasmo de Oliveira². https://orcid.org/0000-0001-9941-3419 \\ Gustavo Santos de Sousa ${ }^{3}$. https://orcid.org/0000-0002-6618-9614 \\ Gilberto Simeone Henriques ${ }^{4}$.https://orcid.org/0000-0002-9110-5427 \\ Dilina do Nascimento Marreiro ${ }^{1 *}$. https://orcid.org/0000-0002-7550-1403
}

\section{Department of Nutrition, Health Sciences Center, Federal University of Piauí, Teresina, Piauí, Brazil. \\ 2. Medimagem Laboratory, Teresina, Piauí, Brazil. \\ 3. Gastrovita Hospital, Teresina, Piauí, Brazil. \\ 4. Department of Nutrition, Nursing School, Federal University of Minas Gerais, Belo Horizonte, Minas Gerais, Brazil.}

*Corresponding author: Dilina do Nascimento Marreiro, Rua Hugo Napoleão, 665, Ed. Palazzo Reale, Apt'. 2001, Jóquei, CEP 64048-320, Teresina, Piauí, Brazil. E-mail: dilina.marreiro@gmail.com.

Este trabajo fue recibido el 16 de agosto de 2020. Aceptado con modificaciones: 18 de octubre de 2020 . Aceptado para ser publicado: 04 de noviembre de 2020.

\begin{abstract}
Background: The objective of this study was to evaluate whether low magnesium concentration is related to increased cardiovascular risk in obese women. Methods: This case-control study included women, who were divided into two groups: case $\left(B M I>35 \mathrm{~kg} / \mathrm{m}^{2}\right)$ and control group $\left(18.5>B M I>24.9 \mathrm{~kg} / \mathrm{m}^{2}\right)$. Body weight, height, waist, neck and hip circumference were measured according to the methodology described by the Ministry of Health. The analyses of plasma, erythrocyte, and urinary magnesium concentrations were performed using the inductively coupled plasma optical emission spectrometry method. The lipid fractions were analyzed according to the enzymatic colorimetric method using a Cobas Integra automatic biochemical analyzer. Results: Mean plasma and erythrocyte magnesium concentrations were lower in the obese women compared to the control group $(p<0.05)$. The urinary excretion of this mineral showed a significant difference between the two groups $(p<0.05)$, and the obese women excreted a higher amount of magnesium in the urine. With regard to the cardiovascular risk parameters, obese women demonstrated higher values compared to the control group $(p<0.05)$. The study showed a negative correlation between erythrocyte magnesium and systolic and diastolic blood pressure in the control group $(p<0.05)$. Conclusion: These results indicate that obese women exhibit changes in nutritional status with regard to magnesium, with reduced concentrations in plasma and erythrocytes, and increased concentration in the urine. However, the results do not suggest a role of magnesium in protection against cardiovascular risk factors in the patients evaluated in this study.
\end{abstract}

Keywords: Cardiovascular risk; Magnesium; Obesity. 


\section{RESUMEN}

El objetivo de este estudio fue evaluar si una concentración baja de magnesio está relacionada con un mayor riesgo cardiovascular en mujeres obesas. Métodos: Este estudio de casos y controles incluyó mujeres, que se dividieron en dos grupos: grupo de casos $\left(I M C>35 \mathrm{~kg} / \mathrm{m}^{2}\right)$ y control $\left(18,5>I M C>24,9 \mathrm{~kg} / \mathrm{m}^{2}\right)$. El peso corporal, la altura, la cintura, la circunferencia del cuello y la cadera se midieron según la metodología descrita por el Ministerio de Salud. Los análisis de las concentraciones de magnesio en plasma, eritrocitos y orina se realizaron utilizando el método de espectrometría de emisión óptica de plasma acoplado inductivamente. Las fracciones lipídicas se analizaron según el método colorimétrico enzimático utilizando un analizador bioquímico automático Cobas Integra. Resultados: Las concentraciones medias de magnesio en plasma y eritrocitos fueron menores en las mujeres obesas en comparación con el grupo de control $(p<0.05)$. La excreción urinaria de este mineral mostró una diferencia significativa entre los dos grupos $(p<0.05)$, y las mujeres obesas excretaron una mayor cantidad de magnesio en la orina. En cuanto a los parámetros de riesgo cardiovascular, las mujeres obesas mostraron valores más altos en comparación con el grupo control $(p<0,05)$. El estudio mostró una correlación negativa entre el magnesio de los eritrocitos y la presión arterial sistólica y diastólica en el grupo de control $(p<0,05)$. Conclusión: Estos resultados indican que las mujeres obesas presentan cambios en el estado nutricional con respecto al magnesio, con concentraciones reducidas en el plasma y eritrocitos, y concentración aumentada en la orina. Sin embargo, los resultados no sugieren un papel del magnesio en la protección contra los factores de riesgo cardiovascular en los pacientes evaluados en este estudio. Palabras clave: Magnesio; Obesidad; Riesgo cardiovascular.

\section{INTRODUCTION}

An excess of adipose tissue can contribute to the manifestation of important biochemical and metabolic disorders such as changes in the lipid metabolism. Dyslipidemia is characterized by an increase in plasma concentrations of triacylglycerols, total cholesterol, and low-density lipoprotein rich in cholesterol (LDL-c) along with a reduction in high-density lipoprotein rich in cholesterol $(\mathrm{HDL}-\mathrm{C})^{2}$.

There are also changes in the metabolism of some minerals in obesity, particularly a reduction in the serum, plasma, and erythrocyte concentrations of magnesium ${ }^{3,4}$. This element plays an important role in lipid metabolism by regulating the activity of enzymes such as 3-hydroxy3-methylglutaryl-coenzyme A reductase (HMG-CoA reductase), lecithin-cholesterol acyltransferase (LCAT), and lipoprotein lipase $(\mathrm{LPL})^{5,6}$.

Regarding the role of magnesium in the activity of the enzyme HMG-CoA reductase, it has been highlighted that this nutrient participates in the Mg-ATP complex, which is a substrate necessary for the phosphorylation process of HMG-CoA reductase, thus inactivating it ${ }^{7}$. Magnesium also activates the enzyme lecithin-cholesterol acyltransferase, which plays a role in reducing the plasma concentration of LDL-c and VLDL-c. It also increases the activity of lipoprotein lipase in muscle tissue, which is an enzyme that contributes to the regulation of the concentration of triacylglycerols and increases HDL-C ${ }^{6,8}$.

Given the presence of metabolic disorders such as dyslipidemia in obese individuals, as well as the important role of magnesium in the activity of the enzymes involved in lipid metabolism contributing to the balance of the cardiometabolic system, the present study aimed to evaluate the concentration of this mineral in different blood components and its relationship with cardiovascular risk markers in obesity. It is plausible that clarifying the possible role of magnesium in the regulation of the lipid metabolism may contribute to nutritional interventions that may be effective in protecting against cardiovascular diseases.

\section{METHODS AND SUBJECTS}

This case-control study involved 115 women aged 20 to 50 years old, who were divided into two groups: case group (obese women with a body mass index over $35 \mathrm{~kg} / \mathrm{m}^{2}$ ) and control group (women with a body mass index between 18.5 and $24.9 \mathrm{~kg} / \mathrm{m}^{2}$ ). Participants were selected through an interview based on the following inclusion criteria: not pregnant or lactating; non-smoker; no history of chronic alcohol intake; not participating in another clinical study; not having a diagnosis of diabetes mellitus, chronic kidney disease, cancer, and/or inflammatory bowel diseases; not using vitamin-mineral supplements and/or medications that could interfere with the magnesium nutritional status and disorders of the lipid metabolism. All the information was self-reported by participants.

The study was registered at Plataforma Brasil and approved by the Research Ethics Committee of the Federal University of Piauí, as provided for in the Resolution 466/12 of the National Health Council (CNS) with an opinion number 2,014,100 . All participants signed an informed consent form.

\section{Assessment of nutritional status}

For anthropometric assessment, body weight, height, waist circumference, neck, and hip measurements were taken according to the methodology described by the Ministry of Health ${ }^{10}$.

\section{Evaluation of cardiovascular risk parameters Determination of lipid profile}

Serum concentrations of total cholesterol, HDLcholesterol, and triacylglycerols were determined by a 
colorimetric enzymatic method, using a COBAS INTEGRA automatic biochemical analyzer with $\mathrm{ROCHE}^{\circledR}$ kits (Roche Diagnostics, Brazil). The LDL-cholesterol fraction was calculated according to the formula of Friedwald et $\mathrm{al}^{11}$ : LDL-C $=\mathrm{CT}-\mathrm{HDL}-\mathrm{C}-\mathrm{TG} / 5$, and was considered valid for values of triacylglycerols up to $400 \mathrm{mg} / \mathrm{dL}$. The values adopted as reference values for the lipid fractions were those defined in the Update of the Brazilian Dyslipidemia and Atherosclerosis Prevention - 2017 ${ }^{12}$.

\section{Waist circumference}

Waist circumference was measured with the participants standing, using a non-extensible tape measure by circling the approximate midpoint between the lower margin of the last palpable rib and the top of the iliac crest. The reference values for assessing the cardiovascular risk using the waist circumference in women were $\geq 80 \mathrm{~cm}$ and $\geq 88 \mathrm{~cm}$, for high and very high risk, respectively ${ }^{13}$.

\section{Hip circumference}

To calculate the waist-to-hip ratio, the hip circumference was measured. The measurement of the hip circumference was performed with the participants standing using a Seca ${ }^{\circledR}$ tape measure (São Paulo, Brazil), which is flexible and not extensible with $0.1 \mathrm{~cm}$ precision. The tape was placed around the hips at the largest diameter area of the gluteal region. The participants were in an upright position while measuring, with the arms away from the body and their feet together ${ }^{13}$.

\section{Neck circumference}

Neck circumference was measured at the midpoint of the cervical spine up to the anterior middle of the neck using a flexible and non-extensible Seca ${ }^{\circledR}$ tape measure (São Paulo, Brazil) with $0.1 \mathrm{~cm}$. The reference values for the classification of the neck circumference with regard to the cardiometabolic risk are: $<34$ (normal), $\geq 34$ (mild risk) and $\geq 36.5$ (high risk) in women ${ }^{14}$.

\section{Waist-to-hip ratio}

The waist-to-hip ratio was calculated by dividing the waist circumference by the hip circumference. The borderline value of the waist-hip ratio associated with the development of complications related to cardiovascular disease is $\geq 0.85$ for women ${ }^{15}$.

\section{Conicity index (ICON)}

This indicator was determined from the measurements of weight, height, and waist circumference, and used to assess obesity and the distribution of body fat. The borderline value of the taper index associated with the development of complications related to obesity and cardiovascular diseases is 1.18 for women ${ }^{16}$.

\section{Determination of Castelli I and II índices}

To determine the risk of cardiovascular disease, Castelli
I and II indices were used, and these correspond to the ratio between total cholesterol and HDL-cholesterol and ratio between LDL-cholesterol and HDL-cholesterol, respectively. The reference values are: Castelli I index $\leq 4.3 \mathrm{mg} / \mathrm{dL}$; Castelli II index $\leq 2.9 \mathrm{mg} / \mathrm{dL}^{17}$.

\section{Blood pressure measurement}

Blood pressure was measured with a digital wrist device from G-Tech, model BP3AF1-3, after the participant was at rest for ten minutes. The reference standard values were: a systolic pressure less than $130 \mathrm{mmHg}$ and diastolic blood pressure less than $85 \mathrm{mmHg}^{18,19}$.

\section{Determination of the biochemical parameters of magnesium}

Samples of $8 \mathrm{~mL}$ of venous blood were collected in the morning between 7 and 9 am, with the participants having fasted for at least 12 hours. The collected blood was distributed in two separate tubes: a polypropylene tube (4 $\mathrm{mL}$ ) containing $30 \%$ sodium citrate as an anticoagulant for the analysis of magnesium and a vacuette ${ }^{\circledR}$ tube $(4 \mathrm{~mL})$ with a clot activator for the determination of the lipid profile.

Plasma was separated from the whole blood by centrifugation (CIENTEC ${ }^{\circledR}$ 4K15, São Paulo, Brazil) at 1831 $\mathrm{x} g$ for 15 minutes at $4{ }^{\circ} \mathrm{C}$. Thereafter, plasma was extracted with an automatic pipette and placed in demineralized polypropylene microtubes which were subsequently kept at $-20^{\circ} \mathrm{C}$. For the separation of erythrocytes and subsequent determination of magnesium, the methods proposed by Whitehouse et $\mathrm{al}^{20}$ were utilized. These comprised washing the erythrocyte mass with $10 \mathrm{~mL}$ of an isotonic saline solution $(0.9 \% \mathrm{NaCl})$, followed by thorough homogenization by inversion, and subsequent centrifugation at $2493 \times \mathrm{g}$ for 10 minutes. This procedure was repeated three times to remove contaminants from the erythrocytes (platelets and leukocytes). After the last centrifugation, the saline solution was aspirated and discarded, and the erythrocyte mass was carefully extracted with the aid of an automatic pipette and transferred to demineralized polypropylene tubes which were kept at $-20{ }^{\circ} \mathrm{C}$ for further analysis.

For 24-hour urine collection, the demineralized containers were weighed before and after the collection on a semi-analytical scale to determine the urine volume from the density. After this procedure, $20 \mathrm{~mL}$ of the urine was removed, distributed between polypropylene microtubes, and stored at $-20^{\circ} \mathrm{C}$ for later measurement of the magnesium concentration.

Plasma, erythrocyte, and urinary magnesium analyses were performed at the Atomic Emission Spectrometry Laboratory - Embrapa (National Corn and Sorghum Research Center), located in Sete Lagoas - Minas Gerais. The elemental analysis of the mineral was performed in an inductively coupled plasma spectrometer - Optical Emission Spectrometry with an axial view configuration and a $\mathrm{V}$-Groove nebulizer (720 ICP / OES, Varian Inc., California, United States). The detection limits were measured using the equation $3 \mathrm{x}$ standard 
deviation of 10 blank measurements, divided by the slope of the calibration curve. Monoelemental stock solutions of magnesium $1000 \mathrm{mgL}^{-1}$ (Titrisol and Certipur - Merck, Germany) were used for the preparation of the reference solutions for the calibration curve and optimization of the analytical conditions. All aqueous solutions and dilutions were prepared using ultrapure water $(18 \mathrm{M} \Omega . \mathrm{cm}-1)$ obtained by means of a Milli-Q system (Millipore, Bedford, MA).

The reference values adopted were 0.75 to 1.05 $\mathrm{mmol} / \mathrm{L}$ for plasma magnesium ${ }^{21}, 1.65$ to $2.65 \mathrm{mmol} / \mathrm{L}$ for erythrocyte magnesium, and 3.00 to $5.00 \mathrm{mmol} / 24 \mathrm{~h}$ for urinary magnesium ${ }^{22}$.

\section{Statistical analysis}

The obtained analytical values were organized in a database in order to perform a descriptive analysis of the variables observed in the two groups. Subsequently, the data were exported to the SPSS program (for Windows ${ }^{\circledR}$ version 22.0) for statistical analysis of the results.

The Kolmogorov-Smirnov test was applied to verify the normality and homoscedasticity of the data. In order to compare the two groups, the Student t-test was used for parametric variables. For the correlation analysis, considering the normal distribution of data, Pearson's linear correlation coefficient was used.

For evaluating the associations, the Chi-square test of Independence and Cramer coefficient were used. For all tests performed, the difference was considered as statistically significant when the $p$ value was $<0.05$ with an error of $5 \%$.

\section{RESULTS}

The mean values and standard deviations of age and the anthropometric parameters used to assess the nutritional status of the participants in this study are shown in table 1. It was observed that there was a statistically significant difference in the parameters of weight, height, and body mass index $(p<0.05)$, these parameters being higher in obese women.

Table 2 shows the concentration of magnesium in the plasma, erythrocytes, and urine in the obese participants

Table 1. Mean values and standard deviations of age, body weight, height and body mass index of participants in the control and obese group. Teresina-PI, Brazil, 2020.

\begin{tabular}{|lccr|}
\hline Parameters & $\begin{array}{c}\text { Control } \\
(\mathbf{n = 5 8 )} \\
\text { Mean } \pm \mathbf{~ S D}\end{array}$ & $\begin{array}{c}\text { Obese } \\
(\mathbf{n = 5 7 )} \\
\text { Mean } \pm \mathbf{S D}\end{array}$ & p \\
\hline Age (years) & $34.5 \pm 8.03$ & $33.91 \pm 8.88$ & 0.600 \\
Body weight $(\mathrm{kg})$ & $55.89 \pm 4.90$ & $104.33 \pm 10.19^{*}$ & $<0.001$ \\
Height $(\mathrm{m})$ & $1.58 \pm 0.07$ & $1.61 \pm 0.06^{*}$ & 0.012 \\
BMl $\left(\mathrm{kg} / \mathrm{m}^{2}\right)$ & $22.32 \pm 1.59$ & $39.93 \pm 3.50^{*}$ & $<0.001$ \\
\hline
\end{tabular}

*Values significantly different between obese participants and control group, Student's t test $(p<0.05)$. BMI= body mass index.

Table 2. Mean values and standard deviations of plasma, erythrocyte and urinary magnesium concentrations of participants in the control and obese groups. Teresina-PI, Brazil, 2020.

\begin{tabular}{|llll|}
\hline Parameters & $\begin{array}{c}\text { Control } \\
(\mathbf{n = 5 8}) \\
\text { Mean } \pm \text { SD }\end{array}$ & $\begin{array}{c}\text { Obese } \\
(\mathbf{n}=\mathbf{5 7}) \\
\text { Mean } \pm \text { SD }\end{array}$ & p \\
\hline Plasma magnesium (mmol/L) & $0.92 \pm 0.11$ & $0.62 \pm 0.10^{*}$ & $<0.001$ \\
Erythrocyte magnesium (mmol/L) & $2.31 \pm 0.23$ & $1.56 \pm 0.12^{*}$ & $<0.001$ \\
Urinary magnesium (mmol/day) & $3.48 \pm 1.69$ & $6.22 \pm 2.46^{*}$ & $<0.001$ \\
\hline
\end{tabular}

*Values significantly different between obese participants and control group, Student's t test $(p<0.05) .{ }^{*} M g$ Urinary: control $(n=54)$, obese $(\mathrm{n}=32) ; \mathrm{Mg}=$ magnesium. Reference values: Plasma magnesium $=0.75$ to $1.05 \mathrm{mmol} / \mathrm{L}^{21}$, Erythrocyte magnesium= 1.65 to $2.65 \mathrm{mmol} /$ $\mathrm{L}$, Urinary magnesium $=3.00$ to $5.00 \mathrm{mmol} / 24 \mathrm{~h}^{22}$. 
and the control group. Obese women exhibited lower magnesium concentration in the plasma and red blood cells and higher concentration in the urine compared to the control group, and the difference was statistically significant $(p<0.001)$.

The mean values and standard deviations of the cardiovascular risk assessment parameters in the obese participants and control group are shown in table 3 . The obese women presented higher values of the parameters of waist circumference, hip circumference, waist-hip ratio, neck circumference, index taper, total cholesterol, triglycerides, non-HDL-c, LDL-C, VLDL, and Castelli I and II indices, together with lower HDL-C values compared to the control group, demonstrating a statistically significant difference $(p<0.05)$.

Table 4 and figure 1 shows the results of the correlation analysis between the magnesium biomarkers and cardiovascular risk indicators (anthropometric and blood pressure measurements) in the obese women. A negative correlation between urinary magnesium and waist and hip circumference $(p<0.05)$ was observed.

Table 5 and figure 2 demonstrate the results of the correlation analysis between the magnesium biomarkers and cardiovascular risk indicators (anthropometric and blood pressure measurements) in the control group. There was a negative correlation between erythrocyte magnesium and systolic and diastolic blood pressure $(p<0.05)$, and a positive correlation between urinary magnesium and waist-to-hip ratio and the taper index $(p<0.05)$. In addition, there was a positive correlation between erythrocyte magnesium and total cholesterol $(\mathrm{p}<0.05)$.

Table 3. Mean values and standard deviations of the cardiovascular risk parameters of the control and obese participants. Teresina-PI, Brazil, 2020.

\begin{tabular}{|c|c|c|c|}
\hline Parameters & $\begin{array}{c}\text { Control } \\
(n=58) \\
\text { Mean } \pm \text { SD }\end{array}$ & $\begin{array}{c}\text { Obese } \\
(n=57) \\
\text { Mean } \pm \text { SD }\end{array}$ & $\mathbf{p}$ \\
\hline WC & $74.36 \pm 4.69$ & $112.32 \pm 9.45 *$ & $<0.001$ \\
\hline $\mathrm{HC}$ & $96.46 \pm 4.74$ & $129.52 \pm 7.36^{*}$ & $<0.001$ \\
\hline WHR & $0.77 \pm 0.05$ & $0.87 \pm 0.06^{*}$ & $<0.001$ \\
\hline NC & $31.68 \pm 2.12$ & $39.80 \pm 2.71 *$ & $<0.001$ \\
\hline ICON & $1.15 \pm 0.06$ & $1.29 \pm 0.08^{*}$ & $<0.001$ \\
\hline TC & $183.58 \pm 22.75$ & $196.45 \pm 26.20^{*}$ & 0.006 \\
\hline TAG & $110.43 \pm 33.81$ & $138.68 \pm 47.93 *$ & $<0.001$ \\
\hline HDL-C & $55.26 \pm 9.06$ & $48.19 \pm 10.17^{*}$ & $<0.001$ \\
\hline Non-HDL-c & $128.79 \pm 23.34$ & $148.21 \pm 24.01 *$ & $<0.001$ \\
\hline LDL-C & $106.75 \pm 21.62$ & $120.52 \pm 23.35^{*}$ & 0.002 \\
\hline VLDL-C & $22.08 \pm 6.76$ & $27.73 \pm 9.58^{*}$ & $<0.001$ \\
\hline Castelli Index I & $3.41 \pm 0.69$ & $4.25 \pm 1.04 *$ & $<0.001$ \\
\hline Castelli Index II & $2.00 \pm 0.58$ & $2.63 \pm 0.84^{*}$ & $<0.001$ \\
\hline SBP & $116.59 \pm 12.52$ & $119.29 \pm 13.80$ & 0.292 \\
\hline DBP & $80.83 \pm 10.10$ & $79.53 \pm 9.62$ & 0.901 \\
\hline
\end{tabular}

* Values significantly different between obese participants and control group, Student's t test $(p<0.05)$. WC= waist circumference; $N C=$ neck circumference; $\mathrm{HC}=$ hip circumference; $\mathrm{WHR}=$ waist-to-hip ratio; $\mathrm{TC}=$ total cholesterol; $\mathrm{TAG}=$ triacylglycerols; $\mathrm{HDL}=$ high density lipoprotein; non-HDL= non-HDL cholesterol; $\mathrm{LDL}=$ low density lipoprotein; $\mathrm{VLDL}=$ very low density lipoprotein; $\mathrm{SBP}=$ systolic blood pressure; $\mathrm{DBP}=$ diastolic blood pressure. High or very high risk values: $\mathrm{WC} \geq 88 \mathrm{~cm}$ [13]; $\mathrm{CP} \geq 36.5$ [14]; $\mathrm{WHR} \geq 0.85$ [15]; ICON= 1.18 [16]; $\mathrm{ICl} \geq 4.3 \mathrm{mg} / \mathrm{dL} ; \mathrm{Cl} \mathrm{II} \geq 2.9 \mathrm{mg} / \mathrm{dL}$ [17]; SBP $>130 \mathrm{mmHg}$; DBP $>85 \mathrm{mmHg}$ [18]. Goals for fasting lipid profile: $\mathrm{CT}<190, \mathrm{HDL}>40, \mathrm{TG}<150$, $\mathrm{LDL}<130$, Non-HDL $<160$ [12]. 
Table 4. Simple linear correlation analysis between magnesium biomarkers and cardiovascular risk indicators (anthropometric and blood pressure and lipid profile) in obese women. Teresina-PI, Brazil, 2020.

\begin{tabular}{|lcccccc|}
\hline Parameters & \multicolumn{2}{c}{ Plasmatic Magnesium } & \multicolumn{2}{c}{ Erythrocyte Magnesium } & \multicolumn{2}{c}{ Urinary Magnesium } \\
& $\mathbf{r}$ & $\mathbf{p}$ & $\mathbf{r}$ & $\mathbf{p}$ & $\mathbf{r}$ & $\mathbf{p}$ \\
\hline WC & 0.057 & 0.676 & 0.129 & 0.339 & -0.372 & $0.036^{*}$ \\
HC & 0.030 & 0.829 & -0.034 & 0.806 & -0.433 & $0.015^{*}$ \\
WHR & 0.104 & 0.444 & 0.225 & 0.095 & -0.114 & 0.541 \\
NC & -0.018 & 0.897 & 0.046 & 0.736 & -0.139 & 0.449 \\
TI & 0.027 & 0.840 & 0.161 & 0.230 & -0.257 & 0.156 \\
SBP & -0.092 & 0.531 & 0.002 & 0.988 & -0.253 & 0.222 \\
DBP & -0.079 & 0.591 & 0.010 & 0.944 & 0.208 & 0.318 \\
TC & -0.115 & 0.396 & 0.224 & 0.093 & -0.185 & 0.311 \\
TAG & 0.210 & 0.116 & 0.152 & 0.258 & 0.036 & 0.843 \\
HDL-C & -0.118 & 0.161 & -0.004 & 0.976 & 0.131 & 0.475 \\
Non-HDL & -0.044 & 0.746 & 0.238 & 0.075 & -0.262 & 0.147 \\
LDL-C & -0.133 & 0.323 & 0.191 & 0.155 & -0.290 & 0.108 \\
VLDL-C & 0.210 & 0.116 & 0.152 & 0.258 & 0.036 & 0.843 \\
CI I & 0.034 & 0.801 & 0.125 & 0.356 & -0.216 & 0.234 \\
CI II & -0.029 & 0.830 & 0.093 & 0.490 & -0.254 & 0.161 \\
\hline
\end{tabular}

*Pearson's Linear Correlation $(\mathrm{p}<0.05)$. WC= waist circumference; $\mathrm{NC}=$ neck circumference; $\mathrm{HC}=$ hip circumference; $\mathrm{WHR}=$ waist-to-hip ratio; $\mathrm{Tl}=$ taper index; $\mathrm{SBP}=$ systolic blood pressure; $\mathrm{DBP}=$ diastolic blood pressure; $\mathrm{TC}=$ total cholesterol; $\mathrm{TAG}=$ triacylglycerols; $\mathrm{HDL}=\mathrm{high}$ density lipoprotein; non-HDL= non-HDL cholesterol; $\mathrm{LDL}=$ low density lipoprotein; $\mathrm{VLDL}=$ very low density lipoprotein; $\mathrm{Cl}=\mathrm{Castelli}$ index.

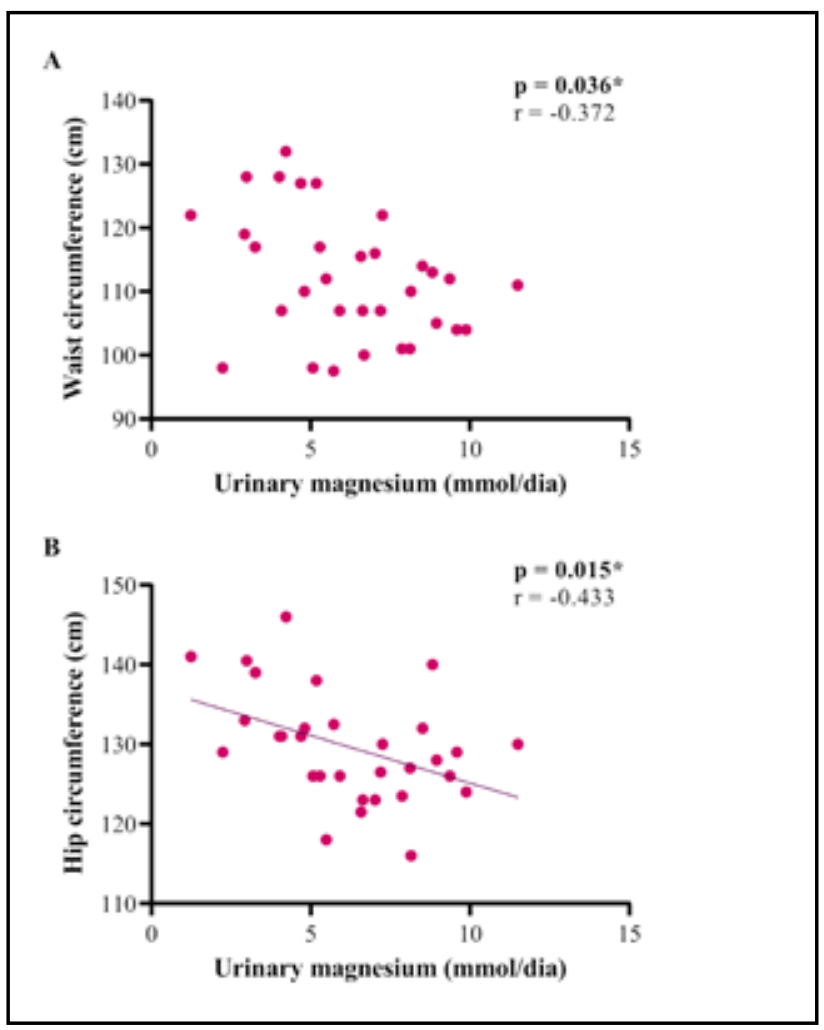

Figure 1: Simple linear correlation analysis between urinary magnesium and indicators anthropometric (waist circumference and hip circumference) in obese women. Teresina-PI, Brazil, 2020.

*Pearson's Linear Correlation $(\mathrm{p}<0.05)$. A: correlation between urinary magnesium and waist circumference. B: correlation between urinary magnesium and hip circumference. 
Table 5. Analysis of simple linear correlation between magnesium biomarkers and cardiovascular risk indicators (anthropometric and blood pressure and profile lipid) in the control group. Teresina-PI, Brazil, 2020.

\begin{tabular}{|llllccc|}
\hline Parameters & \multicolumn{2}{c}{ Plasmatic Magnesium } & \multicolumn{2}{c}{ Erythrocyte Magnesium } & \multicolumn{2}{c|}{ Urinary Magnesium } \\
$\mathbf{r}$ & $\mathbf{p}$ & $\mathbf{p}$ & $\mathbf{p}$ & $\mathbf{p}$ \\
\hline WC & & 0.144 & -0.179 & 0.179 & 0.253 & 0.065 \\
HC & 0.194 & 0.232 & -0.061 & 0.654 & -0.070 & 0.617 \\
WHR & 0.161 & 0.562 & -0.196 & 0.144 & 0.287 & $0.035^{*}$ \\
NC & 0.078 & 0.497 & -0.241 & 0.073 & 0.038 & 0.789 \\
TI & 0.093 & 0.371 & -0.163 & 0.225 & 0.284 & $0.038^{*}$ \\
SBP & 0.121 & 0.858 & -0.265 & $0.044^{*}$ & -0.047 & 0.736 \\
DBP & 0.024 & 0.788 & -0.276 & $0.036^{*}$ & -0.141 & 0.310 \\
TC & -0.036 & 0.868 & 0.295 & $0.024^{*}$ & 0.077 & 0.579 \\
TAG & -0.022 & 0.827 & 0.162 & 0.225 & 0.104 & 0.455 \\
HDL-C & 0.029 & 0.410 & 0.166 & 0.218 & 0.092 & 0.511 \\
Non-HDL & -0.111 & 0.859 & 0.226 & 0.091 & 0.066 & 0.638 \\
LDL-C & 0.024 & 0.819 & 0.193 & 0.153 & 0.044 & 0.757 \\
VLDL-C & 0.019 & 0.827 & 0.162 & 0.225 & 0.103 & 0.454 \\
CI I & 0.029 & 0.710 & 0.060 & 0.658 & -0.041 & 0.769 \\
CI II & 0.050 & 0.689 & 0.064 & 0.639 & -0.038 & 0.789 \\
\hline
\end{tabular}

* Pearson's Linear Correlation $(\mathrm{p}<0.05)$. WC= waist circumference; $\mathrm{NC}=$ neck circumference; HC= hip circumference; WHR= waist-to-hip ratio; $\mathrm{Tl}=$ taper index; $\mathrm{SBP}=$ systolic blood pressure; $\mathrm{DBP}=$ diastolic blood pressure; $\mathrm{TC}=$ total cholesterol; $\mathrm{TAG}=$ triacylglycerols; $\mathrm{HDL}=\mathrm{high}$ density lipoprotein; non-HDL= non-HDL cholesterol; $\mathrm{LDL}=$ low density lipoprotein; $\mathrm{VLDL}=$ very low density lipoprotein; $\mathrm{Cl}=\mathrm{Castelli}$ index.

A

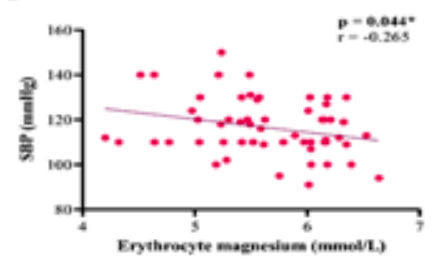

D

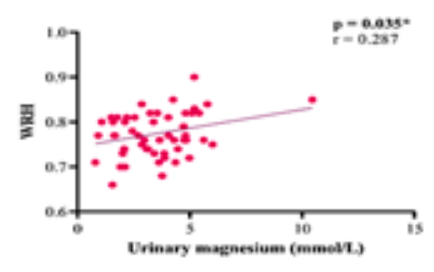

B
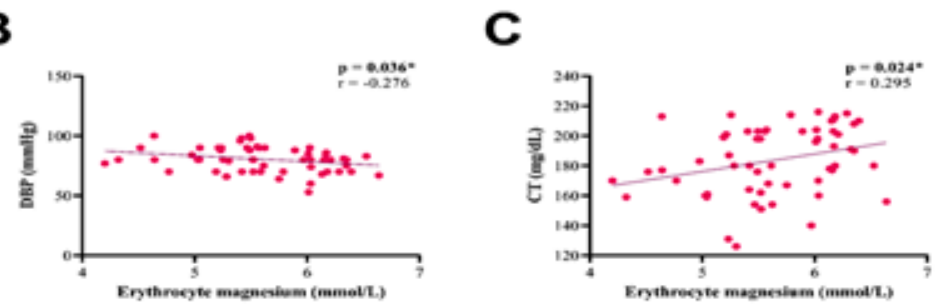

$\mathbf{E}$

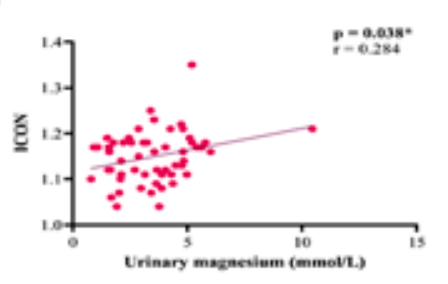

Figure 2: Simple linear correlation analysis between erythrocyte magnesium and indicators blood pressure (SBP and DBP) and urinary magnesium and indicators anthropometric (ICON and WRH) in obese women. Teresina-PI, Brazil, 2020.

*Pearson's Linear Correlation $(\mathrm{p}<0.05)$. A: correlation between erythrocyte magnesium and systolic blood pressure; B: correlation between erythrocyte magnesium and diastolic blood pressure; C: correlation between erythrocyte magnesium and total cholesterol; D: correlation between urinary magnesium and waist-to-hip ratio; E: correlation between urinary magnesium and taper index. 


\section{DISCUSSION}

In this study, we evaluated magnesium biomarkers in obese women, as well as the existence of a correlation between these variables and cardiovascular risk parameters. With regard to magnesium, obese women showed reduced concentrations of the element in the plasma compared to the control group, and this may be attributed to the low intake of the nutrient. Data from the Brazilian Family Budget Survey (2018-2019) show that the prevalence of inadequate food consumption of this mineral is approximately $69.2 \%{ }^{23}$.

Other factors that may have contributed to the reduced concentration of magnesium in the plasma may be the changes in the process of its absorption into the enterocytes or increased urinary excretion. In addition, high calcium or fat intake can interfere with the absorption of magnesium in the gastrointestinal tract ${ }^{24,25}$. Similar data were obtained in studies conducted by Hassan et $\mathrm{al}^{24}$ and Bertinato et $\mathrm{al}^{26}$, and their findings reported reduced plasma magnesium concentrations in children and obese women, respectively.

We obtained similar results on analysis of the erythrocyte magnesium concentration, with a statistically significant difference between the obese women and control group, and values below the normal range in the obese group. Erythrocyte magnesium is a marker used for medium to long-term evaluation of the mineral in the body; thus, a reduction in its value reveals possible chronic depletion of the nutrient. Other studies from the same research perspective have also yielded similar data such as those conducted by Zemva et $\mathrm{al}^{27}$.

Oxidative stress and chronic low-grade inflammation, which are considered characteristics of obesity, may be the contributing factors for the reduction of magnesium in erythrocytes. This is because in the presence of these disorders, magnesium leaves the blood and is transported to cells in order to neutralize free radicals and minimize the inflammatory process, consequently, leading to its reduction in the blood compartment ${ }^{28,29}$. The negative consequences of hypomagnesaemia include systemic arterial hypertension, hypercholesterolemia, and hypertriglyceridemia ${ }^{30}$.

With regard to urinary magnesium, our results show that obese women excreted a higher amount of this element compared to the control group. This result reinforces the existence of alterations in the magnesium homeostasis in obese individuals, because even with decreased concentration of the mineral in plasma and erythrocytes, the obese patients exhibited inefficient renal retention of this nutrient.

Furthermore, low-grade chronic inflammation may also be considered a relevant factor for the increased excretion of magnesium in the urine, since it increases the activity of the enzyme $1-\alpha$-hydroxylase vitamin $D$, which is capable of increasing renal calcium reabsorption, which in turn leads to increased urinary magnesium excretion ${ }^{5,31}$.

In case of cardiovascular risk parameters, our results showed a statistically significant difference for anthropometric markers (waist circumference, hip circumference, waist-hip ratio, neck circumference, taper index) and biochemical parameters (total cholesterol, triglycerides, HDL-c, nonHDL-c, LDL-C, VLDL, and Castelli I and II indices) between the groups. These data show that abdominal obesity is commonly associated with an increased risk of cardiovascular disorders and contributes to dyslipidemia ${ }^{32,33}$.

In order to obtain a better understanding of the role of magnesium in protection against cardiovascular risk factors, a correlation analysis was carried out between the mineral parameters and biomarkers of cardiovascular risk. Despite the absence of such a correlation in this study, it is important to draw attention to the fact that magnesium deficiency in the medium and long term may be a contributing factor for dyslipidemia and consequently, for cardiovascular diseases.

On the other hand, the data obtained from the control group revealed an inverse correlation between erythrocyte magnesium and systolic and diastolic blood pressure. This result confirms the functions of magnesium in the vascular endothelium and vascular smooth muscle cells, where it acts as a calcium inhibitor, promotes vasodilation, and inhibits platelet aggregation. Similarly, a study by Abbasi et al ${ }^{34}$ showed a negative correlation between serum magnesium concentration and systolic and diastolic blood pressure.

Although magnesium is essential for enzymes that participate in the lipid metabolism, including liver lipase, lipoprotein lipase, and lecithin-cholesterol acyltransferase, the effects of chronic mineral deficiency on adipocyte function and lipid metabolism remain largely unknown ${ }^{35}$.

Some factors may have limited the results found in the study, such as the assessment of body composition only by $\mathrm{BMI}$ and the inclusion of only female individuals as a criterion to participate in the research. In addition to the fact that the size and density of lipoproteins has not been quantified and direct analysis of the apolipoproteins involved in lipid metabolism was not yet been performed may have limited a more in-depth discussion on the role of magnesium in protection against cardiovascular risk factors in the evaluated patients.

Importantly, previous studies have consistently demonstrated the important physiological functions performed by magnesium in the cardiovascular system, as well as the complexity of the mechanisms involved in these functions. Therefore, although the results of this study may not suggest an important function, it is necessary to continue further research on this topic in order clarify the role of magnesium.

\section{CONCLUSION}

The results of this study demonstrate that obese women have inadequate magnesium concentrations, with reduced values in the plasma and erythrocytes as well as a high cardiovascular risk. The study did not show any association between magnesium and markers of cardiovascular risk. However, further research is required in order to clarify the possible participation of this nutrient in the regulation of lipid metabolism, and thus formulate nutritional interventions that may be effective in protecting against cardiometabolic diseases. 
Founding source: This research was self-funded.Conflicts of interests. The authors declare having no conflicts of interest.

\section{REFERENCES}

1. Mika A, Sledzinski T. Alterations of specific lipid groups in serum of obese humans: A review. Obes Rev. 2017; 18: 24772.

2. Rhee EJ, Kim HC, Kim JH, Lee EY, Kim BJ et al. Guidelines for the management of dyslipidemia in Korea. Korean J Intern Med. 2019; 34: 1171.

3. Cruz KJ, Oliveira AR, Pinto DP, Morais JBS, Lima FS et al. Influence of magnesium on insulin resistance in obese women. Biol Trace Elem Res. 2014; 160: 305-310.

4. Severo JS, Morais JBS, Freitas TEC, Cruz KJC, Oliveira ARS et al. Metabolic and nutritional aspects of magnesium. Nutr Clín Diet Hosp. 2015; 35: 67-74.

5. Oliveira ARS, Cruz KJC, Severo, JS, Morais JBS, Freitas TEC et al. Hypomagnesemia and its relation with chronic lowgrade inflammation in obesity. Rev Assoc Med Bras. 2017; 63: 156-163.

6. Simental-Mendía LE, Simental-Mendía M, Sahebkar A, Rodríguez-Morán M, Guerrero-Romero F. Effect of magnesium supplementation on lipid profile: a systematic review and meta-analysis of randomized controlled trials. Eur J Clin Pharmacol. 2017; 73: 525-536.

7. Rosanoff A, Seelig MS. Comparison of mechanism and functional effects of magnesium and statin pharmaceuticals. J Am Coll Nutr. 2004; 23: 501-505.

8. Rotter I, Kosik-Bogacka D, Dotegowska B, Safranow K, Karakiewicz $B$ et al. Relationship between serum magnesium concentration and metabolic and hormonal disorders in middle-aged and older men. Magnesium Res. 2015; 28: 99107.

9. Brazil. Ministry of Health. Resolution No. 466/12. National Council for Research with Human Beings. Federal Official Gazette. Brasília, 2012.

10. Brazil. Ministry of Health. Department of Health Care. Department of Primary Care. Food and nutrition surveillance Sisvan: Basic guidelines for the collection, processing, analysis of data and information in health services. Brasilia: Ministry of Health, 2004.

11. Friedewald WT, Levy RI, Fredrickson DS. Estimation of the concentration of low-density lipoprotein cholesterol in plasma, without use of the preparative ultracentrifuge. Clin Chem. 1972; 18: 499-502.

12. Faludi AA, Izar MCO, Saraiva JFK, Chacra APM, Bianco HT et al. Update of the Brazilian guideline on dyslipidemia and prevention of atherosclerosis. Arq Bras Cardiol. 2017; 109: 1-76.

13. World Health Organization. Waist Circumference and WaistHip Ratio: Report of a WHO Expert Consultation. Geneva, 2008.

14. Ben-Noun L, Laor A. Relationship between changes in neck circumference and changes in blood pressure. Amer J Hypertens. 2004; 17: 409-414.

15. World Health Organization. Obesity: Preventing and managing the global epidemic. Report of a WHO Consulation on Obesity. Genebra (Suíça), 1998.

16. Pitanga FJG, Lessa I. Sensitivity and specificity of the taper index as a discriminator of coronary risk in adults in Salvador, Brazil. Rev Bras Epidemiol. 2004; 7: 259-269.

17. Castelli WP, Abbot WD, McNamara PM. Summary estimates of cholesterol used to predict coronary heart disease. Circulation. 1983; 67: 730-734.

18. Andrade JP, Nobre F. VI Brazilian Guideline for Hypertension. Arq Bras Cardiol. 2010; 95: 1-51.

19. Malachias MVB, Souza WKSB, Plavnik FL, Rodrigues CIS, Brandão AA et al. 7th Brazilian Guideline for Hypertension. Arq Bras Cardiol. 2016; 107: 1-83.

20. Whitehouse RC, Prasad AS, Rabbani PI, Cossack ZT. Zinc in plasma, neutrophils, lymphocytes, and erythrocytes as determined by flameless atomic absorption spectrophotometry. Clin Chem. 1982; 28: 475-480.

21. Topf JM, Murray PT. Hypomagnesemia and hypermagnesemia. Rev Endocr Metab Disord. 2003; 4: 195-206.

22. Tietz NW. Clinical guide to laboratory test. 3 ed. Philadelphia: W.B. Saunders Company, 1995.

23. Brazil. Research of family budgets 2017-2018: analysis of personal food consumption in Brazil. IBGE, work and income coordination - Rio de Janeiro: IBGE, 2020.

24. Hassan SA, Ahmed I, Nasrullah A, Haq S, Ghazanfar H et al. Comparison of serum magnesium levels in overweight and obese children and normal weight children. Cureus. 2017; 9: e1607.

25. DiNicolantonio Jl, O'keefe JH, Wilson W. Subclinical magnesium deficiency: a principal driver of cardiovascular disease and a public health crisis. Open Heart. 2018; 5: e000668.

26. Bertinato J, Xiao CW, Ratnayake WMN, Fernandez L, Lavergne $C$ et al. Lower serum magnesium concentration is associated with diabetes, insulin resistance, and obesity in South Asian and white Canadian women but not men. Food Nutr Res. 2015; 59: 25974.

27. Zemva A, Zemva Z. Ventricular ectopic activity, left ventricular mass, hyperinsulinemia, and intracellular magnesium in normotensive patients with obesity. Angiology 2000; 51: 101-106.

28. Baaij JHF, Hoenderop JGJ, Bindels RJM. Regulation of magnesium balance: Lessons learned from human genetic disease. Clin Kidney J. 2012; 5: 15-24.

29. Romero ABR, Lima FS, Colli C. Mg status in inflammation, insulin resistance, and associated conditions. Nutrire. 2017; 42: 6 .

30. Song Y, Li TY, Van Dam RM, Manson JE, Hu FB. Magnesium intake and plasma concentrations of markers of systemic inflammation and endothelial dysfunction in women. Am J Clin Nutr. 2007; 85: 1068-1674.

31. Farhangi MA, Ostadrahimi A, Mahbood S. Serum calcium, magnesium, phosphorous and lipid profile in healthy Iranian premenopausal women. Biochem Med. 2011; 21: 312-320.

32. Elmaoğullari S, Tepe D, Uçaktürk SA, Kara FK, Demirel F. Prevalence of dyslipidemia and associated factors in obese children and adolescents. J Clin Res Pediatr Endocrinol. 2015; 7: 228-234.

33. Qi Q, Strizich G, Hanna DB, Giacinto RE, Castañeda SF et al. Comparing measures of overall and central obesity in relation to cardiometabolic risk factors among US Hispanic/ Latino adults. Obesity (Silver Spring). 2015; 23: 1920-1928.

34. Abbasi IU, Salim-Ul-Haque, Kausar MW, Karira KA, Zubaris $N A$. Correlation of divalent cat ions (Ca2+, Mg2+) and serum renin in pateints of essential hypertension. J Pak Med Assoc. 2012; 62: 134-138.

35. Kurstjens S, Van Diepen JA, Overmars-Bos C, Alkema W, Bindels RJM et al. Magnesium deficiency prevents high-fatdiet-induced obesity in mice. Diabetologia 2018; 61: 20302042. 